\title{
SOME ASPECTS OF THE CENOZOIC GLACIATION OF SOUTHERN VICTORIA LAND, ANTARCTICA
}

\author{
By HOWARD BRADY \\ (School of Biological Sciences, Macquarie University, North Ryde, New South Wales 2113 , \\ Australia) \\ and BARRIE MCK ELVEY \\ (Department of Geology, University of New England, Armidale, New South Wales 2351, \\ Australia)
}

\begin{abstract}
Palaeoglacial evidence at three sites in southern Victoria Land has been examined to consider the possible uplift of the Transantarctic Mountains through the East Antarctic ice sheet prior to the Middle Miocene. A Cenozoic tillite at Mount Feather and a striated pavement at Mount Brooke pre-date uplift. Another tillite remnant adjacent to Odell Glacier near Mount Brooke post-dates the uplift and is locally derived. This tillite. together with the Mount Feather tillite, has been previously placed in the Sirius Formation, a term that the authors abandon as it covers tillites of varying ages. Basement complex derived clasts in the Mount Feather tillite. previously reported by these authors, could be inherited from the Jurassic Mawson Formation or the Permian Metschel Tillite but they still provide evidence that the Mount Feather tillite was deposited by a regional glaciation.
\end{abstract}

RÉsumÉ. Quelques aspects de la glaciation cenozö́c en Victoria Land du Sud. Antarctique. Des traces paléoglaciaires ont été examiné en trois points dans le Sud de la Victoria Land pour envisager le possible soulèvement des Transantarctic Mountains à travers la calotte glaciaire de l'Est Antarctique avant le milieu du Miocène. Une tillite cenozoïque à Mount Feather et un dallage striè à Mount Brooke sont antérieurs au soulèvement. Une autre trace de tillite voisine du Odell Glacier près de Mount Brooke, postérieure au soulèvement est localement mise en évidence. Cette tillite comme celle du Mount Feather, avait été d'abord placé dans la "formation de Sirius", une expression que les auteurs abandonnent parce qu'il englobait des tillites d’âges différents. Les éclats dérivant d'une roche-mer complexe dans la tillite du Mount Feather, autrefois décrite par ces auteurs, pourraient provenir de la formation jurassique de Mawson ou de celle, permienne. des tillites de Metschel. mais elles apportent une nouvelle preuve que la tillite de Mount Feather a été déposée lors d'une glaciation régionale.

Zusammenfassung. Einige Bemerkungen zur känozoischen Vereisung von Süd-Victoria-Land. Antarklika. Zur Feststellung einer möglichen Hebung der Transantarctic Mountains durch den ostantarktischen Eisschild vor dem mittleren Miozän wurden paläoglaziale Beobachtungen an drei Stellen im südlichen Victoria-Land herangezogen. Ein känozoischer Tillit am Mount Feather sowie die geriefte Verebnung am Mount Brooke gingen der Hebung voraus. Reste eines anderen Tillits am Rande des Odell Glacier nahe Mount Brooke folgten ihr: sie sind lokal abgelagert. Dieser Tillit wurde zusammen mit dem Mount Feather-Tillit früher der Sirius-Formation zugeordnet, ein Ausdruck, den die Autoren ablehnen, da er Tillite verschiedenen Alters umfasst. Grundschichten des Mount Feather-Tillites, über die die Autoren früher berichtet haben, können aus der jurassischen MawsonFormation oder aus dem permischen Metschel-Tillit stammen; doch beweisen sie nach wie vor, dass der Mount Feather-Tillit durch eine regionale Vereisung abgelagert wurde.

THE uplift of the Transantarctic Mountains during the Tertiary has preserved an ancient tillite at $2750 \mathrm{~m}$ on Mount Feather in southern Victoria Land from subsequent erosion by ice-sheet advances since the Middle Miocene (Brady and McKelvey, 1979). We have since found new data which relate to the provenance of this tillite. We now have palaeo-ice-flow evidence from a striated pavement preserved at $2700 \mathrm{~m}$ on Mount Brooke in the Coombs Hills of southern Victoria Land (Fig. 1). Our investigation of another Cenozoic tillite exposed at $1600 \mathrm{~m}$ on the northern edge of the Coombs Hills has important 


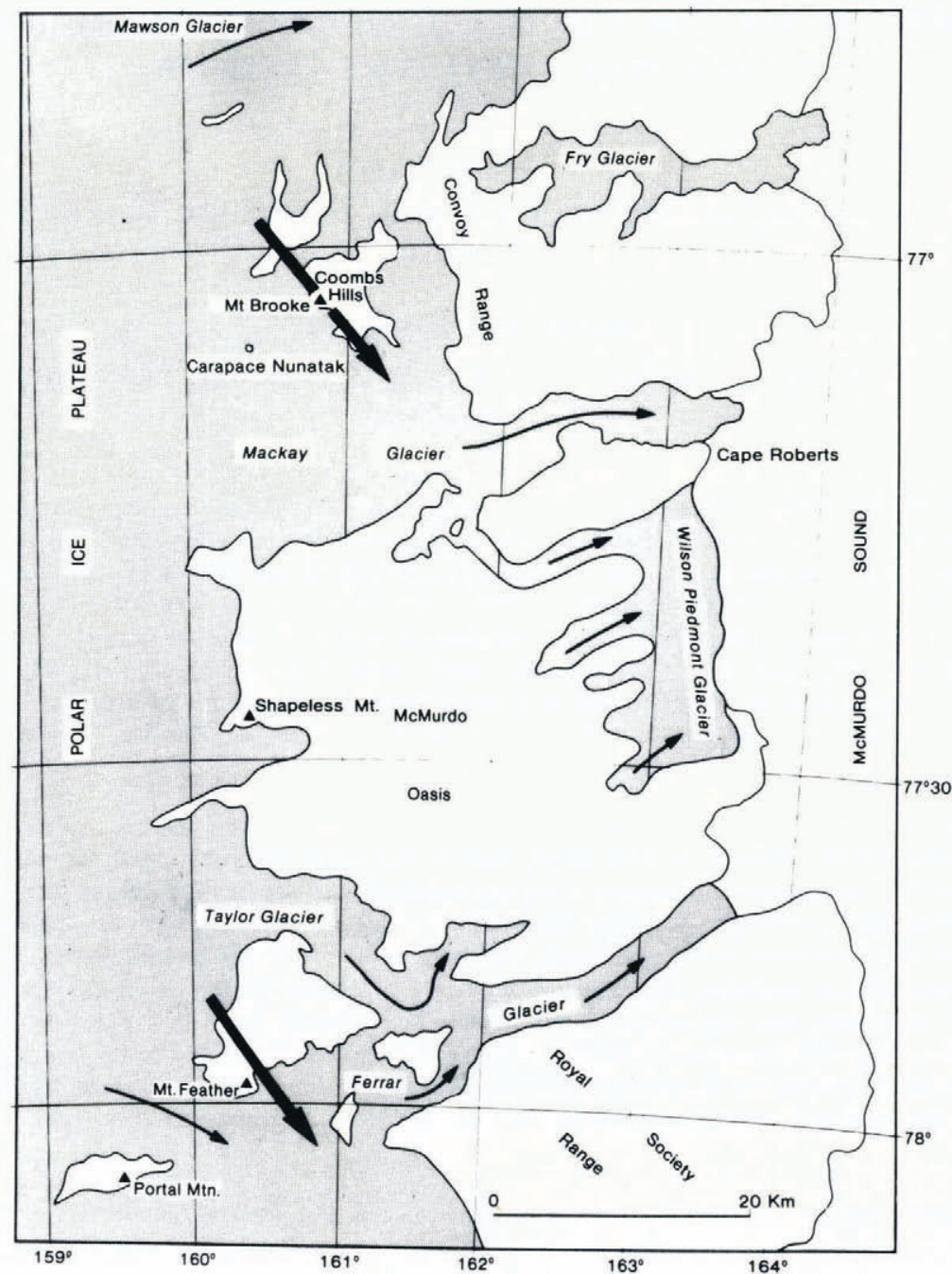

Fig. 1. The positions of Mount Brooke and Mount Feather in southern Victoria Land. The palaeo-ice-flow' direction. determined from the pavement at Mount Brooke, is indicated as also is the palaeo-ice-flow direction indicated b! the Cenozoic tillite exposed on Mount Feather (Brady and McKelve!, 1979). The contrast between these two ice flow directions and that of the present regional ice-flow pattern is apparent. The younger tillite on the north western edge of the Coombs Hills is also shown (marked by an asterisk).

implications concerning the relative ages of these glacial features at the three localities. Our data at Mount Feather and Mount Brooke suggest that the Transantarctic Mountains may have been uplifted through a precursor of the present East Antarctic ice sheet: an event which may have modified ice-drainage patterns in southern Victoria Land.

\section{Provenance of the Mount Feather tillite}

In our previous article, we stated (Brady and McKelvey, 1979, p. 192) that the Mount Feather tillite was a distal (valley-glacier) deposit. Taking into account the altitude of the tillite $(2750 \mathrm{~m})$ and the altitude 
of the nearest exposed basement rocks $(1400 \mathrm{~m})$, we felt that the only source for the metasediment erratics must have been some tens of kilometres inland beneath the present ice sheet, where radio echo-sounding data suggest the presence of crystalline basement complex rocks (Drewry, 1982). Although we still hold the tillite to be a relatively distal deposit, the metasediment-clast evidence we used is no longer entirely valid.

Recently, in the Coombs Hills (between Mawson Glacier and Mackay Glacier), we had the opportunity to examine the Jurassic Mawson Formation which there disconformably overlies the Beacon Supergroup. The Mawson Formation (of the Ferrar Group) is composed of volcanic mudflows, explosion breccias and volcaniclastic sandstones; and at some localities pillow lavas and hyaloclastites are exposed. The Mawson Formation is considered to be the result of Ferrar Dolerite magmas being extruded subaerially (Grapes and others, 1974). With this we agree. However, in closely examining the formation, we found a few rounded acid plutonic boulders (i.e. basement complex derived) lying on the surface and at one locality granitic clasts were seen in situ within the otherwise volcaniclastic formation. Only acid pegmatitic and granodioritic clasts (up to $1 \mathrm{~m}$ ) were observed. At most outcrops, however, we could find no clasts derived from a basement complex.

The Mawson Formation is not exposed in the Mount Feather area, presumably having been removed by Cenozoic erosion, but it is likely to exist nearby at shallow subglacial depth beneath the present edge of the East Antarctic ice sheet. It is conceivable that the Mawson Formation could have been the source of the metasediment (i.e. basement complex derived) clasts within the Mount Feather tillite. Furthermore, the palaeo-ice-flow direction towards $145^{\circ}$ of the Mount Feather tillite indicates a source area inland from the Coombs Hills, relatively close to where the Mawson Formation crops out (i.e. Carapace Nunatak). and where it is presumably extensive subglacial. For this reason, we can no longer suggest on the metasediment-clast evidence that the source terrain of the Mount Feather tillite was perhaps up to $100 \mathrm{~km}$ inland from the present edge of the East Antarctic ice sheet.

\section{SigNifiCANCE OF BASEMENT COMPLEX CLASTS IN SOME CENOZOIC TILLS}

We cannot readily account for the presence of rounded acid plutonic clasts in the volcaniclastic Mawson Formation. In the Coombs Hills area, the formation disconformably overlies the Triassic Lashly Formation and in places the Permian Weller Coal Measures. It is conceivable that locally the disconformity may reach down as far as the Permian Metschel Tillite, and this would allow for the possibility of the basement complex clasts being re-worked from that glacigenic unit. Webb (1974) has suggested basement complex boulders within or on Cenozoic moraines are inherited from nearby outcrops of the Metschel Tillite. Other workers have interpreted the presence of plutonic and metamorphic boulders on the surface of inland moraines (composed essentially of Ferrar Dolerite clasts and a sand matrix largely derived from the Beacon Supergroup) to indicate ice flow from areas where basement complex rocks are exposed (Linkletter and others, 1974, p. 727; Claridge and Campbell, 1978).

In many instances we would disagree with both of these points of view. Many of the basement complex boulders we feel are derived from the erosion of older Cenozoic tillites similar to the remnant we described containing metasediment clasts at $2750 \mathrm{~m}$ on Mount Feather. Because of their otherwise nearly identical clast composition (i.e. Beacon Supergroup sediments and Ferrar Dolerite) to the younger Cenozoic tills and moraines mantling valley and cirque floors, the former presence of these older tillites is indicated only by the re-worked exotic boulders. We believe the older tillites to have been widespread in southern Victoria Land but few have survived either subsequent erosion or in situ disintegration by weathering.

\section{Striated PaVement - Mount Brooke}

A striated pavement remnant has recently been discovered near the summit of Mount Brooke on the western edge of the Coombs Hills (Figs 1 and 2). The pavement fragment is at an altitude of about $2700 \mathrm{~m}$ and covers an area of about $0.8 \mathrm{~km}^{2}$. The pavement is approximately $700 \mathrm{~m}$ above the level of the adjacent polar ice plateau but has obviously been cut by plateau-derived ice. The palaeo-ice-flow direction indicated by the striated surface of the pavement is towards $142^{\circ}$, parallel to that we determined recently for the tillite and the sub-tillite pavement at Mount Feather (Brady and McKelvey, 1979 p. 192). (The precise height of Mount Brooke is not known. On the USGS Convoy Range 1:250 000 topographic sheet 


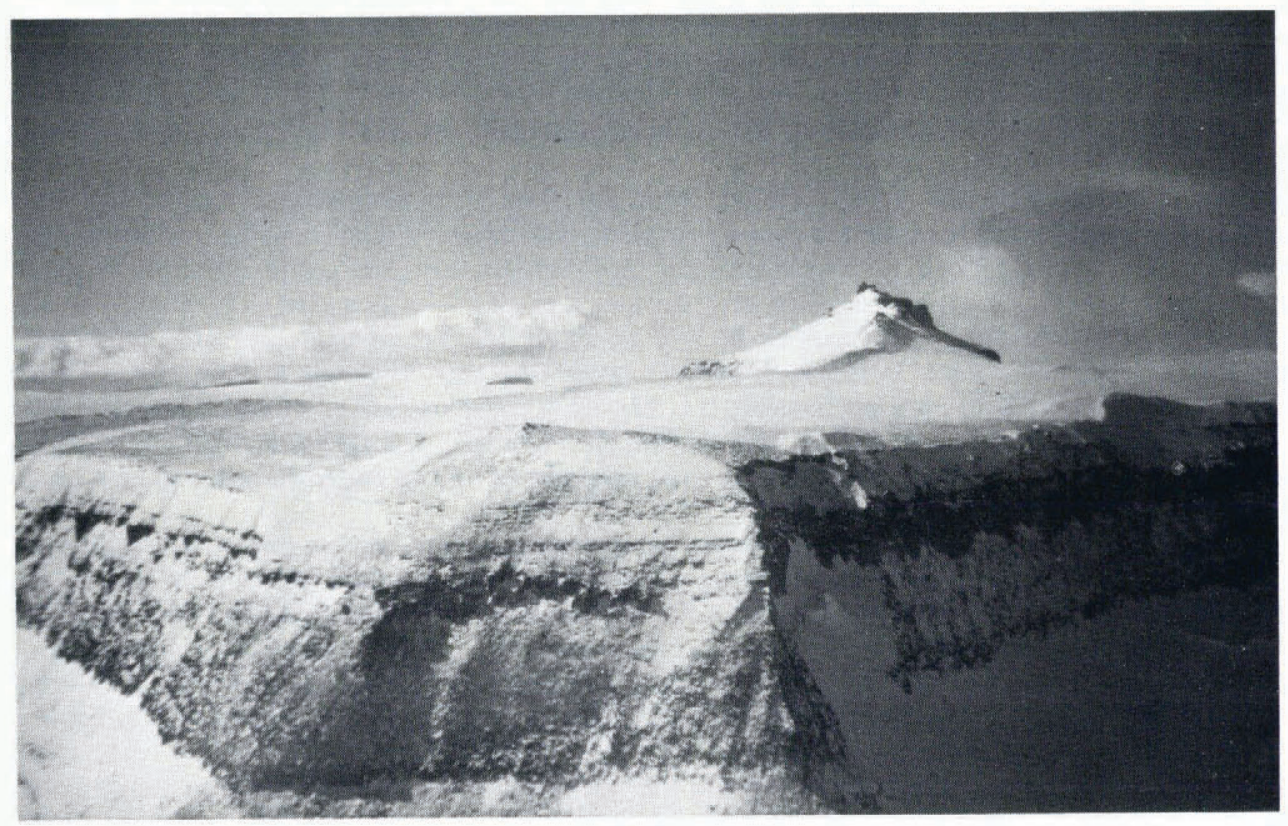

Fig. 2. Mount Brooke, Coombs Hills, southern Victoria Land. Aerial view from above the polar plateau looking eastnorth-eastward towards the coast. A small tableland covering an area of approximatel. $0.8 \mathrm{~km}^{2}$ abuts the summit arête of Mount Brooke. The tableland has an altitude of approximately $2700 \mathrm{~m}$ and is surfaced by a glacial pavement trending towards $142^{\circ}$, i.e. from left to right.

ST57-60/1 it is shown as $2675 \mathrm{~m}$. The altitude of the pavement used here is based on frequent helicopter altimeter readings, which suggest the height of Mount Brooke is approximately $2800 \mathrm{~m}$.)

Mount Brooke is a relatively isolated peak on the western edge of the Transantarctic Mountains overlooking the East Antarctic ice sheet. To the north, the nearest peaks of similar altitude are more than $260 \mathrm{~km}$ away at the southern end of the Eisenhower Range in northern Victoria Land. In the intervening area relatively few mountains occur as isolated small ranges and nunataks studding or bordering very large glaciers such as David, Reeves, and Mawson Glaciers. To the south of Mount Brooke, the closest peaks with comparable altitudes are Shapeless Mountain $(2739 \mathrm{~m})$ and Mount Feather $(2985 \mathrm{~m}) .75$ and $125 \mathrm{~km}$ distant, respectively. The Cenozoic tillite and striated pavement at $2750 \mathrm{~m}$ on Mount Feather we have already referred to, and a tillite (not yet examined by us) occurs at approximately $2500 \mathrm{~m}$ on Shapeless Mountain (Mayewski, 1975).

These three glacigene features are the only ones so far recorded at such high altitudes in southern Victoria Land. Although they need not be exactly contemporaneous, we consider that they provide evidence for a widespread phase of glacial erosion. It may be coincidental that our palaeo-ice-flow directions at Mount Brooke and Mount Feather are both from the north-west but we feel that both localities provide evidence for a drainage system which differs from the Miocene to present-day drainage system of the dry valleys and adjacent areas of southern Victoria Land.

Drewry (1980) has now suggested that the regional flow of plateau ice to the west of the dry valleys is controlled by a local ice dome $100 \mathrm{~km}$ wide inland from the western edge of the Transantarctic Mountains. Radio echo-sounding contours of sub-ice-sheet bedrock topography show that ice flows from this dome southward to Skelton Glacier, eastward to the dry valleys and northward to Mackay, Mawson, and David Glaciers. These ice-flow directions are in marked contrast to those we recorded at Mount Feather and Mount Brooke, and yet we have no doubt that both were cut by plateau-derived ice. Admittedly. the palaeo-ice-flow direction may reflect some local topographic control and the similar flow directions may be 
coincidental, but polar plateau-derived ice could not have cut the Mount Feather and Mount Brooke pavements unless the plateau ice was over $700 \mathrm{~m}$ thicker in the past or unless the mountains were lower. Conceivably, a combination of both possibilities may have occurred.

Drewry (1980) has shown that the ice dome on the western edge of the dry valleys has thickened in the past and has caused eastward advances of plateau-derived glaciers through the dry valleys. However. we feel that an increase of $700 \mathrm{~m}$ thickness in this dome is most unlikely in recent times, for it would leave much more evidence of overriding in the dry-valley system at altitudes above $2000 \mathrm{~m}$. Even if this did occur, we cannot see how north-easterly flowing ice from this dome could produce south-easterly trending striations and chatter marks on the Mount Brooke pavement. Furthermore, since the Mount Brooke pavement overlooks the edge of the polar plateau and towers over the surrounding area. we cannot see any topographic feature which could have modified regional ice-flow direction by approximately $90^{\circ}$. Certainly, there has been no recent major thickening of the polar plateau ice adjacent to Mount Brooke. Drewry (1980) has argued that meteorites with ages ranging from 30000 to 800000 years lie on the ice surface just west of the Allan and Coombs Hills, and indicate that the ice sheet has not substantially thickened during this time; otherwise, the meteorites would have been flushed down Mawson Glacier. This evidence supports our view that modern ice could not have formed the glacial bench at Mount Brooke. now $700 \mathrm{~m}$ above the ice-sheet surface.

Brady (unpublished) has shown that Wright Valley was a shallow marine fjord in the Middle Miocene; evidence derived from shallow marine benthic diatoms in a deposit now $104 \mathrm{~m}$ above sea-level on the north-eastern edge of Lake Vanda (Fig. 3). This evidence, together with the presence of in-situ stacked shells dated as early Pliocene in a marine deposit at Prospect Mesa $165 \mathrm{~m}$ above present-day sea-level on the floor of Wright Valley (Webb, 1974; Brady, unpublished), indicates that there has been little uplift of Wright Valley since the Middle Miocene (possibly less than $400 \mathrm{~m}$ ). The presence of till overlying the Prospect Mesa section in Wright Valley, together with glacial benches up to 1500 m. indicates an expanded ice sheet or ice dome in the late Miocene or early Pliocene but these features do not explain the glacial bench on Mount Brooke or the tillite on Mount Feather at $2700 \mathrm{~m}$. Even though there is evidence of lower sea-levels in the late Miocene and of a large East Antaretic ice sheet at that time (Mayewski. 1975), ice near the edge of the dry-valley system would have to have been $1000 \mathrm{~m}$ above the glacial benches in Wright Valley to override high sections of Mount Feather or Mount Brooke, a situation that these authors consider unlikely. Even though it is difficult to base a water-tight argument on only two localities, we think that our evidence raises the possibility that Mount Brooke and Mount Feather were uplifted through ice prior to substantial uplift in southern Victoria Land, prior to the formation of the modern ice dome described by Drewry, and prior to the Miocene to present-day ice-drainage pattern.

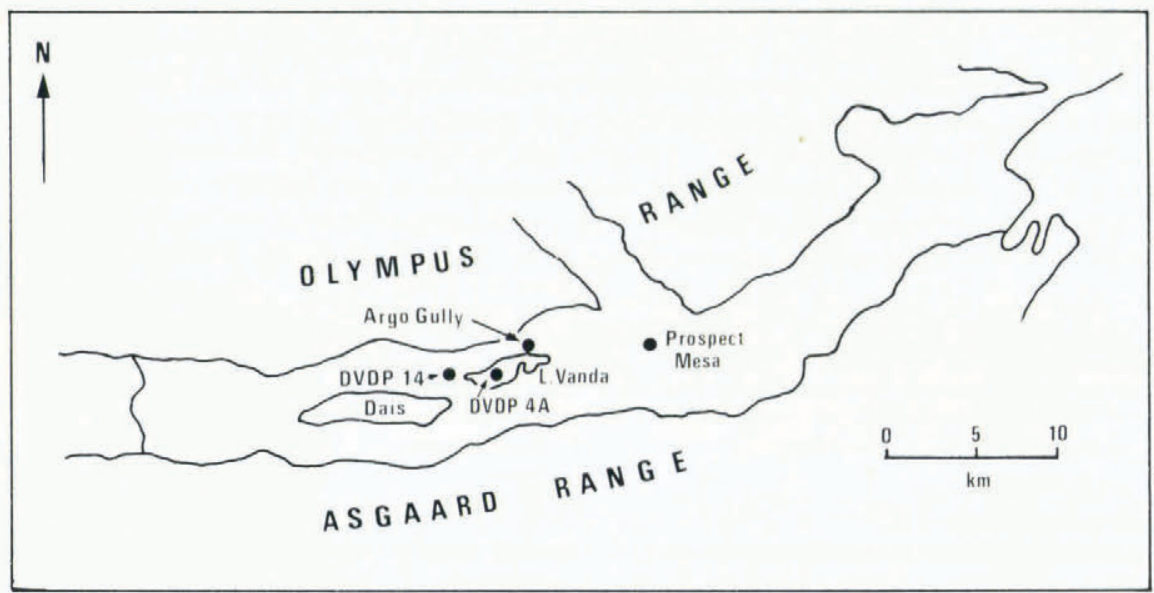

Fig. 3. Middle to early late Miocene fjord sediments occur at Argo Gully on the shore of Lake Vanda and in the lower section of Dry. Valle! Drilling Project (DVDP) hole 4A; some of these may hate been re-worked. In-situ early. Pliocene shallow marine sediments occur at Prospect Mesa. 
Today, southern Victoria Land is a coastal region but it must be remembered that continental rocks underlie Oligocene sediments in the western Ross Sea (Hayes and others, 1975), so that in the early Tertiary the area of the Coombs Hills and the dry valleys was not coastal but part of the Antarctic hinterland. We therefore see the uplift of the Transantarctic Mountains, the development of the Ross Sea graben, and changes in early glacial drainage patterns within a newly formed coastal region as related events.

Conceivably, differential movement during uplift provided some gaps through which the ponded ice sheet was channelled directly to the newly formed coast. We assume the ancestral David Glacier originated in this manner. The channelling would have become more pronounced during uplift and would have created the fjords which were later drained during uplift in the Pliocene (Webb. 1972) to form the dry valleys of the McMurdo "oasis". It is also possible that heatiward erosion of alpine glaciers originating from néve fields in the youthful Transantarctic Mountains breached the mountain chain and so allowed additional eastward drainage of plateau ice towards the coast.

\section{COOMBS HILLS TILLITE}

We recently examined a Cenozoic lodgement tillite exposed in the northern Coombs Hills at lat. $76^{\circ} 43^{\prime}$ S., long. $160^{\circ} 07^{\prime} \mathrm{E}$. overlooking Odell Glacier. This exposure is possibly the one referred to by Mayewski (1975, p. 20). The tillite occurs as a steeply inclined $\left(30^{\circ}\right)$ veneer up to $4 \mathrm{~m}$ thick distributed over a vertical distance of $80 \mathrm{~m}$. It rests on Lashly Formation sandstones of the Beacon Supergroup and passes beneath Odell Glacier ice at approximately $1600 \mathrm{~m}$.

The tillite is a massive diamictite containing blocks up to $3 \mathrm{~m}$ in diameter. No fabric was obvious. The largest blocks are of dolerite and usually striated. Other (smaller) clasts include Beacon Supergroup quartzose sandstones, carbonaceous sandstones, and siltstones or silty mudstones. No clasts of either the Jurassic Kirkpatrick Basalt or of the Jurassic Mawson Formation lavas, breccias and volcaniclastic sandstones were observed.

Because of the striking absence of clasts of these two formations, which together constitute so much of the Coombs Hills and adjacent Allan Hills, we feel the tillite was not deposited from polar plateau-derived ice. Instead, we suggest it has been deposited by an expanded Curreen Glacier flowing north-west into Odell Glacier from a local neve field further to the east in the Convoy Range.

Taking into account this presumed palaeo-ice-flow direction, and the altitude of the outcrop, we consider the tillite to be considerably younger than the nearby but $1100 \mathrm{~m}$ higher Mount Brooke pavement. Whereas the Mount Brooke pavement pre-dates (in our view at least) much if not all of the uplift of the Transantarctic Mountains chain, the Coombs Hills tillite post-dates this same uplift. Mayewski (1975) also considered Cenozoic tillites (Sirius Formation) in the Coombs Hills and nearby Allan Hills to post-date the sculpturing of the Transantarctic Mountains. However. Mayewski considered these tillites to be of the same age as that at Mount Feather; with this we would disagree. We consider the tillite exposed on the edge of Odell Glacier to be similar to that described by Barrett and Powell (1982) at Table Mountain, since both are locally derived deposits which presumably post-date most of the uplift of the Transantarctic Mountains, as they both have been deposited within the Miocene to present-day drainage system. As such, they cannot be grouped with the older glacial features we have described at Mount Feather and Mount Brooke as belonging to the Sirius Formation, a term that should now be abandoned.

\section{CONCLuSIONS}

1. Palaeo-ice-flow data obtained from the tillite exposed on Mount Feather and the glacial pavement preserved near the summit of Mount Brooke suggest to us that the Transantarctic Mountains in southern Victoria Land may have been uplifted during the Tertiary through the continental East Antarctic ice sheet.

2. The drainage pattern of the ice sheet in southern Victoria Land may have been modified by this uplift.

3. Further evidence for pre-uplift ice-flow directions in southern Victoria Land is necessary as our case is based on only two localities. Portal Mountain and the Warren Range, as well as Shapeless Mountain, should be investigated. 
4. A Cenozoic tillite preserved in the northern Coombs Hills adjacent to Odell Glacier post dates at least much of the uplift of the Transantarctic Mountains. It was deposited from ice derived from a local neve field and is unrelated to flow from the East Antarctic ice sheet.

5. Basement complex derived clasts in Cenozoic tillites are not necessarily reliable indicators of the glacial erosion of basement terrains at that time. We consider it highly probable that many such rock types are inherited from the Jurassic Mawson Formation as well as the Permian Metschel Tillite.

\section{ACKNOWLEDGEMENTS}

The authors are grateful for the support of Dr P. J. Barrett and the Victoria University Antarctic Research Centre. We acknowledge financial assistance from the Transantarctic Association (N.Z.) and also research grants from Macquarie University, Sydney, and the University of New England. Armidale. During our high-altitude camps, K. Woodford's mountaineering expertise was invaluable as was the helicopter support of the United States "Operation Deep Freeze".

MS. received 27 March 1981 and in revised form 22 January 1982

\section{REFERENCES}

Barrett, P. J., and Powell, R. D. 1982. Middle Cenozoic glacial beds at Table Mountain, southern Victoria Land. (In Craddock, C., ed. Antarctic geoscience. S!mposium on Antarctic Geolog!' and Geoph'sics, Madison, Wisconsin. U.S.A., August 22-27, 1977. Madison, University of Wisconsin Press, p. 1059-67. (International Union of Geological Sciences, Ser. B, No. 4.))

Brady, H. T. Unpublished. Palaeoenvironmental and biostratigraphic studies in the McMurdo and Ross Sea regions. Antarctica. [Ph.D. thesis, Macquarie University, 1980.|

Brady, H. T., and McKelvey B. C. 1979. The interpretation of a Tertiary tillite at Mount Feather, southern Victoria Land, Antarctica. Journal of Glaciolog1, Vol. 22, No. 86, p. 189-93.

Claridge, G. G. C., and Campbell, I. B. 1978. Moraines of probable Miocene age, dry valleys. Antarctica. New: Zealand Antarctic Record, Vol. 1, No. 2, p. 1-5.

Drewry, D. J. 1980. Pleistocene bimodal response of Antarctic ice. Nature, Vol. 287. No. 5779, p. 214-16.

Drewry, D. J. 1982. Ice flow, bedrock, and geothermal studies from radio-echo sounding inland of McMurdo Sound. Antarctica. (In Craddock, C., ed. Antarctic geoscience. Symposium on Antarctic Geologl and Geophrics. Madison, Wisconsin, U.S.A., August 22-27, 1977. Madison, University of Wisconsin Press, p. 977-83. (International Union of Geological Sciences, Ser. B, No. 4.))

Grapes, R. H., and others. 1974. Shallow dolerite intrusion and phreatic eruption in the Allan Hills region. Antarctica. by R. H. Grapes, D. L. Reid, J. D. McPherson. New Zealand Journal of Geology and Geophysics, Vol. 17. No. 3. p. $563-77$.

Hayes, D. E., and others. 1975. Initial Reports of the Deep Sea Drilling Project (Scripps Institution of Oceanography. University of California), Vol. 28. | Volume is by 12 authors.|

Linkletter, G., and others. 1973. Soils and glacial deposits in the Beacon Valley, southern Victoria Land, Antarctica. by G. Linkletter, J. Bockheim, F. C. Ugolini. New Zealand Journal of Geolog! and Geophısics, Vol. 16. No. I. p. $90-108$.

Mayewski, P. A. 1975. Glacial geology and late Cenozoic history of the Transantarctic Mountains. Antarctica. Ohio State University, Institute of Polar Studies, Report No. 56.

Webb, P. N. 1972. Wright Fjord, Pliocene marine invasion of an Antarctic dry valley. Antarctic Journal of the United Siates, Vol. 7, No. 6, p. 225-34.

Webb, P. N. 1974. Derivation of the older moraines in Beacon Valley, Antarctica. New Zealand Journal of Geolog.' and Geophysics, Vol. 17, No. 3, p. 723-28. [Letter.| 